\title{
Seasonal variation of water quality and waste loads in Buriganga river with GIS visualization
}

\author{
M. K. Alam, M. A. Uddin, M. F. Satter and N. Majed* \\ Department of Civil Engineering, University of Asia Pacific, 74/A Green Road, Dhaka-1205
}

Received: 29 August 2018

Revised: 05 September 2019

Accepted: 11 November 2019

DOI: https://doi.org/10.3329/bjsir.v55i2.47632

\begin{abstract}
Pollution status of the Buriganga river has been assessed in this study using GIS tool to analyze the spatial and seasonal distribution of several water quality parameters from six surface water sampling stations. In addition, characterization of water quality from certain selected outfalls discharging wastewater along the river was accomplished as well. The observed surface water quality concentration was higher during dry season for BOD $_{5}(13.68-22.8 \mathrm{mg} / \mathrm{l}), \mathrm{COD}(22-30 \mathrm{mg} / \mathrm{l})$, TDS (280- $303 \mathrm{mg} / \mathrm{l}), \mathrm{PO}_{4}(5.6-7.3 \mathrm{mg} / \mathrm{l})$ while an exception was found for $\mathrm{NH}_{3}-\mathrm{N}(0.67-0.89 \mathrm{mg} / \mathrm{l})$ and Turbidity (25.19 to 91.18 ). The DO level was found noticeably lower during dry season (1.73 to $2.36 \mathrm{mg} / \mathrm{l}$ ) than wet season (3.27 to $4.68 \mathrm{mg} / \mathrm{l}$ ). Moreover, Principal Component Analysis identified high ionic distributions during wet season and more organic pollution during dry season. Water quality parameters TDS, TSS, EC and COD were obtained in high concentration levels from industrial outfalls towards the downstream of the river while $\mathrm{BOD}_{5}, \mathrm{NH}_{3}-\mathrm{N}$ were higher from municipal wastewater outfalls towards the upstream of the river. The observed pollution loading from the outfalls revealed the location at Dholaikhal as the major pollution source in the river with a BOD $_{5}(11681-12243 \mathrm{~kg} /$ day) and TDS (9749- $32348 \mathrm{~kg} /$ day) loading. Accordingly, influence of nearest wastewater sources on the surface water quality was evident through GIS representation of the parameters.
\end{abstract}

Keywords: Buriganga river; GIS; Outfalls; Seasonal variation; Spatial distribution; Waste load

\section{Introduction}

Buriganga River, the lifeline of Dhaka city is considerably most polluted among the surrounding four rivers around the city (Sarker, 2005). In recent years, both the width and the flow rate of the river have reduced due to the building up of illegal manmade structures and waste dumping in the banks of the river. The changes in hydrodynamic properties of the river is also influencing the self-cleansing property of the river. With increasing pollution load, the sign is very alarming for the existence of the river. The most significant sources of wastewater in the river are industries along the bank of the river. There are 627 dying industries located beside the Buriganga River and near 5000 cubic meter effluents are discharged every day from these industries (Ahammed et al., 2016). Previous studies also identified 22 large industrial outlets along the Buriganga river (Rahman and Bakri, 2010). The existing sewerage system is quite old and major northern parts of the mega city Dhaka is still out of sewerage coverage (DWASA, 2014). Lack of adequate sewerage system results in direct discharge of municipal waste into the river or nearby water body which is eventually carried out to the Buriganga river. These untreated wastes are harmful for existing aquatic ecosystem and water quality in the river. The situation is even worse during dry season with reduced water flow and low rainfall flushing. In orderto ascertain the overall impact on surface water quality, identification of wastewater sources and characterization of discharge sources are important. In addition, it will be of interest to analyze the distribution of water quality parameters along the river to evaluate the water quality profile of the river stretch and identify pollution zones in the river.

Efforts have been made in previous studies to investigate the surface water quality in the Buriganga river to understand seasonal and temporal variation of water quality parameters 
(Rahman and Bakri, 2010; Saifullah et al., 2013; Ahammed et al., 2016; Sarkar et al., 2015). The waste loading from potential sources in the Buriganga River was estimated in the study by Kamal et al. (1999) along with the investigation of pollution status in the river. Some researchers used GIS tools to specify sampling locations in the Buriganga river for analyzing water quality parameters (Moniruzzaman et al., 2009; Rahman and Hossain, 2008). One previous study by Ouyang et al. (2006) showed the use of principal component analysis to associate between water quality parameters and variation of the levels of parameters between different seasons, whereas Gao et al. (2015) used principal component analysis and hierarchical cluster analysis to understand pollution status and source of the Pu river.This study (Gao et $a l ., 2015)$ also exhibited spatial distribution of water quality parameters of $\mathrm{Pu}$ river in China using spatial interpolation method in GIS to classify different pollution zones in the river. However, no such elaborated study using GIS has been performed for Buriganga river so far to understand the spatial distribution of water quality parameters in the river.

The present study attempted to identify major wastewater outfalls and characterize outfalls' discharge along with surface water quality of the river in two different seasons. Through the evaluation of water quality parameters from the selected outfalls and surface water quality in the proximity of the sources, the intention was to understand the impact of outfalls discharge on the river water quality. The observed levels of water quality parameters were also compared with the Bangladesh Environment Conservation Rule 1997 (ECR,1997). Moreover, GIS analysis was performed along with the statistical analysis of water quality to represent important water quality parameters in the river stretch.

\section{Materials and methods}

\section{Study area}

Buriganga river flows at the north central region of Bangladesh near Dhaka city with a total length of $25 \mathrm{~km}$ from Mirpur to Fatulla (Haque, 2008). Originating from the river Turag near Aminbazar Bridge at Mirpur, it falls at Shitalakhya river near Naraynganj (Haque, 2008). Flow characteristics of the Buriganga river is non-tidal during dry season and tidal in wet season. In dry season, the flow of the river is near nonexistent and water level remains lower (SWMC, 1996). For evaluating the distribution of wastewater sources along the river stretch, the study was performed along $6 \mathrm{~km}$ of the river stretch from Mitford to Pagla near Naraynganj (Figure 1). With densely populated area in both sides of the river at upstream of the study area, most of the wastewater sources are from municipal sewage connections. The large wastewater outlet Dholai khal used to discharge at the midstream of the study area, does not exist anymore and now converted into a box culvert (Rahman and Rana, 1996). Many textile industries are mushroomed in downstream of the study area near Dhaka-Narayanganj highway at Narayanganj.

\section{Sampling stations}

Six wastewater outfalls and six surface water sampling stations were selected near individual outfalls for water sampling as delineated in Figure 1. The outfalls were identified through field trips around the Buriganga river using boat and were selected depending on their magnitude of discharge, size and location. Sampling stations were selected considerable distance away towards downstream from the selected outfalls to assess the impact of the outfall discharge on the river water quality. The water samples were collected from six outfalls and six water sampling stations for two different seasons. The wet season sampling was done in August 2017 and the dry season sampling was done in December 2017.

\section{Sample collection and analysis}

One-liter size pre washed PVC bottles were used for the sampling and before sampling the sample bottles were washed with sample water to maintain the accuracy of sampling. The wastewater samples from the outfalls were collected at the discharging point. The surface water samples were collected considerable distance away towards downstream in the river from each of the outfalls and at one feet depth from the water surface to avoid floating pollutants and scums. Water samples were analyzed for twelve water quality parameters during wet and dry seasons which are $\mathrm{pH}$, color, turbidity, electrical conductivity (EC), total dissolved solids (TDS), total suspended solids (TSS), dissolved oxygen (DO), 5-day biochemical oxygen demand $\left(\mathrm{BOD}_{5}\right)$, chemical oxygen demand (COD), ammonia-nitrogen $\left(\mathrm{NH}_{3}-\mathrm{N}\right)$, nitrate-nitrogen $\left(\mathrm{NO}_{3}-\mathrm{N}\right)$ and phosphate $\left(\mathrm{PO}_{4}\right)$. The dissolved oxygen, $\mathrm{pH}$, TDS, TSS and EC were analyzed in laboratory setup using multiparameter (Model: Hach HQ40D) as per standard methods (APHA, 1992). Ammonia nitrogen was measured by Nessler method while phosphate and nitrate-nitrogen were analyzed by Molybdovanadate and Cadmium reaction method respectively using the spectrophotometer; these experiments were also done following the standards (APHA, 1992). The color and turbidity were measured using platinum-cobalt and Nephelometric method respectively as per the standard method (APHA, 1992). The BOD $_{5}$ was analyzed with BOD trak II (Model: Hach) and BOD incubator (Model: Hach FOC120E) using potassium hydroxide and BOD nutrient buffer pillow reagent by BODTRAK method mentioned in 


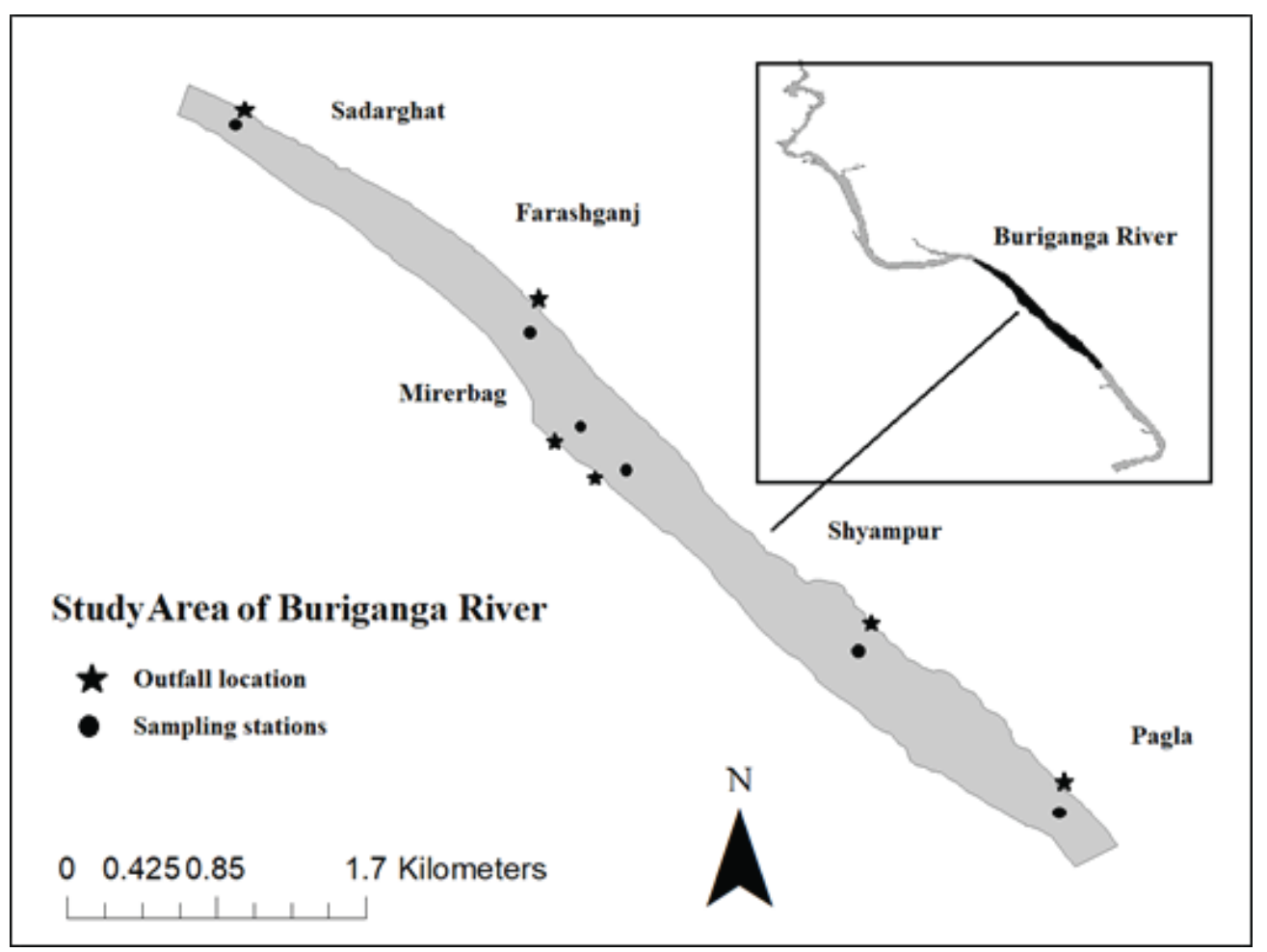

Fig. 1. Selected outfalls and surface water sampling stations in the study area of Buriganga river

the study (Hach et al., 1997). The COD was measured using COD reactor (Model: Hach DRB200) and Spectrophotometer (Model: Hach DR 6000) by reactor digestion method (Jirka and Carter, 1975).

\section{Waste loading estimation}

Flow rate of the outfalls were ascertained during the dry season in December 2017. The dry season was chosen for the measurement due to low water level which would facilitate in identifying the route of water discharge from the outfalls. The whole waste loading method was done using distance method from the study by Sabit (2011) rather than involving any special flow measurement equipment. The first step is measurement of cross sectional area of the flow through the outfalls. Later, the velocity through the outfalls were measured using a flowing object by the time it travels a specific distance (Sabit, 2011). Eventually flow rate was obtained multiplying the cross sectional area of flow and measured velocity of discharge. After the flow measurement, the waste loading rate pertaining to respective pollutant was estimated by multiplying the concentration of the respective pollutant with the estimated flow rate stated by Kamal (1996). Waste loading rate of the outfalls were measured for wet and dry seasons, only using the dry season flow rate. Flow rates for total three outfalls $(\mathrm{O} 1, \mathrm{O} 3, \mathrm{O} 5)$ were measured through direct measurements during the field visit. However, flow rate of outfall O4 was not measured due to the inconsistent and insignificant flow during the flow measurement period. Thus, outfall $\mathrm{O} 4$ was omitted from waste loading estimation.

\section{Data analysis: GIS and statistical methods}

Spatial interpolation involves estimating the values of properties at non sampledsites within an area under existing observations (Ian et al., 2001). In this study, spatial interpolation method was used to show the spatial distribution of water quality parameters in the study area using the data collected from six surface water sampling stations. Total seven water quality parameters from six different sampling stations were processed using krigging method in Arcmap 10.2 as described in Gao et al. (2015). For using krigging approach, a georeferenced GIS map of the study area was prepared and attribute table was created with measured water quality parameter data.

Cluster analysis is known for unsupervised pattern detection method which partitions different cases that are dissimilar to other groups (Zhang et al., 2009). Hierarchical cluster analysis abbreviated as HCA hereafter was applied in the 
study using squared Euclidean distance and ward method for forming group of outfalls according to the discharge quality.

Principal component analysis (PCA) involves simple and meaningful representation of the factors by decreasing the contribution to PC's of variables with minor significance and increasing the more significant ones (Vega et al., 1998). This study used PCA analysis to identify major pollutant factors in different seasons of Buriganga river.

In this study, the mathematical and statistical computation was performed using the statistical software SPSS 20.

\section{Results and discussions}

Seasonal variation of outfall discharge

Table I displays the analysis results of water quality parameters from the outfalls discharge in two different seasons. The selected outfalls in this study could be categorized either as municipal or industrial outfalls depending on the sources of the wastewater that the outfalls are discharging. Outfalls $\mathrm{O} 1$ and $\mathrm{O} 2$ along the upstream zone were municipal outfalls and the rest (O3, O4, O5 and O6) were industrial outfalls. Compared to municipal waste water outfalls, water quality parameters such as COD, TDS, TSS and $\mathrm{EC}$ were found to be higher in general at the industrial outfalls ( $438 \%, 157 \%, 517 \%$ between average levels for the mentioned parameters respectively). Suffice it to say, the chemical contents used in the industries seem to be responsible for the increase in ionic distributions (TDS, EC) whereas untreated effluents with particulate matter might have caused the high TSS concentration. The seasonal variation of the water quality parameters revealed an increasing trend from wet to dry season for most of the industrial outfalls except at O6. The reduced concentration might be caused due to production rate on nearby factories and reduced rainfall which carried more wastewater during the wet season from surrounding industries. Meanwhile, at municipal outfalls, $\mathrm{BOD}_{5}$ and $\mathrm{PO}_{4}$ levels were obtained at high concentrations mainly during the dry season (more than $5 \%$ and $47 \%$ respectively than wet season). In contrast, $\mathrm{NH}_{3}-\mathrm{N}$ was surprisingly higher (more than $5 \%$ ) during the

Table I. Water quality parameters of outfalls discharge in two different season

\begin{tabular}{|c|c|c|c|c|c|c|c|c|c|c|c|c|}
\hline \multirow{2}{*}{ Para. } & \multicolumn{2}{|c|}{ O1 } & \multicolumn{2}{|c|}{$\mathrm{O} 2$} & \multicolumn{2}{|c|}{$\mathrm{O} 3$} & \multicolumn{2}{|c|}{$\mathrm{O} 4$} & \multicolumn{2}{|c|}{ O5 } & \multicolumn{2}{|c|}{ O6 } \\
\hline & Wet & Dry & Wet & Dry & Wet & Dry & Wet & Dry & Wet & Dry & Wet & Dry \\
\hline $\mathrm{pH}$ & 7.78 & 7.04 & 7.05 & 7.03 & 7.35 & 7.12 & 7.42 & 7.91 & $9.39^{*}$ & 7.87 & $9.94 *$ & 8.67 \\
\hline $\begin{array}{c}\mathrm{BOD}_{5} \\
\mathrm{mg} / \mathrm{l}\end{array}$ & 9.98 & $136.8^{*}$ & $104 *$ & $109.44 *$ & $121^{*}$ & $209.76^{*}$ & 27 & 45.6 & $58^{*}$ & $108.3 *$ & $129 *$ & 42.6 \\
\hline $\begin{array}{l}\mathrm{COD} \\
\mathrm{mg} / 1\end{array}$ & 14 & 197 & 252 & 174 & 477 * & $661 *$ & 105 & 126 & 80 & $310 *$ & $295 *$ & 199 \\
\hline $\begin{array}{l}\mathrm{PO}_{4} \\
\mathrm{mg} / 1\end{array}$ & 3.2 & $41.6^{*}$ & 34 & $50 *$ & 75.2 & 76 & 24.9 & 27.3 & 17.1 & 58.5 & 37.7 & 43.2 \\
\hline $\begin{array}{l}\mathrm{NO}_{3}-\mathrm{N} \\
\mathrm{mg} / 1\end{array}$ & 0 & 3.2 & 0 & 0.2 & 7.3 & 5.8 & 0 & 0.3 & 0 & 0 & 0 & 0 \\
\hline $\begin{array}{l}\mathrm{NH}_{3}-\mathrm{N} \\
\mathrm{mg} / \mathrm{l}\end{array}$ & 0.74 & 0.7 & 26.05 & 0.55 & 22.15 & 1.55 & 11.2 & 14.75 & 6.4 & 22.05 & 3.85 & 3.1 \\
\hline $\begin{array}{l}\mathrm{TDS} \\
\mathrm{mg} / \mathrm{l}\end{array}$ & 63 & 462 & 337 & 409 & 504 & 750 & 161.8 & 280 & 275 & 776 & 766 & 502 \\
\hline $\begin{array}{l}\mathrm{TSS} \\
\mathrm{mg} / \mathrm{l}\end{array}$ & 17 & $141^{*}$ & $119^{*}$ & $122 *$ & $791 *$ & $207 *$ & $238 *$ & 108 & 54 & 84 & $285 *$ & 54 \\
\hline $\begin{array}{l}\mathrm{EC} \\
\mathrm{mg} / 1\end{array}$ & 132.4 & 930 & 692 & 824 & 1026 & $1483 *$ & 336 & 565 & 568 & $1512 *$ & $1541 *$ & 995 \\
\hline
\end{tabular}

According to the standard (ECR, 1997), designated unsafe for *: discharge into water body 
wet season compared to dry season. The reason could be due to the high chance of augmented surface runoff through municipal outfalls during wet season, which brings off more ammonia compounds in the river. Among the municipal outfalls, the highest seasonal variation was observed at outfall O1 (varied $300 \%$ to $1307 \%$ ) whereas the highest concentration was obtained at outfall $\mathrm{O} 2$ for most of the parameters. Comparing of observed data from the municipal and industrial outfalls revealed that, DO level was higher at the industrial outfalls discharge during both the seasons (Mainly O5 and O6). The higher DO level is indicative of lesser amount of organic pollutants at industrial outfalls than that in the municipal outfalls. Concentration levels of most of the parameters exceeded the standards for wastewater discharge into water body as specified in the standard (ECR, 1997) which are indicated in the table with asterisks.

\section{Grouping of outfalls by discharge quality}

Data of two different seasons with total 12 water quality parameters from six different wastewater outfalls were processed for HCA, analysis was attempted with ward method for clustering and Squared Euclidean distance was used as computed range. A dendogram was created grouping the six wastewater outfalls into two clusters (Figure 2). The first group comprised wastewater outfalls $\mathrm{O} 2, \mathrm{O} 4, \mathrm{O} 3$ and $\mathrm{O} 1$ in the Buriganga river. Although, the outfalls $\mathrm{O} 3$ and $\mathrm{O} 4$ were identified and categorized as industrial outfalls through field observation, however the HCA analysis grouped these outfalls in the similar category as the municipal outfalls based on the discharge characteristics. This outcome indicates that these outfalls also discharge municipal wastewater along with industrial effluents. Accordingly, the outfalls were observed to contain high amount of $\mathrm{BOD}_{5}, \mathrm{COD}$ and $\mathrm{PO}_{4}$ indicative of organic pollution On the other hand, the other two industrial wastewater outfalls $\mathrm{O} 5$ and $\mathrm{O} 6$ were grouped as another cluster. Accordingly, this cluster could be characterized to contain discharge of similar water quality as both outfalls within the cluster carry industrial wastewater from local textile industries. Field observation also confirmed that these outfalls usually carry heavy textile dye.

\section{Seasonal variation of surface water quality}

Figures 3 through 12 show the spatial and temporal variation of water quality parameters $\mathrm{pH}, \mathrm{BOD}_{5}, \mathrm{COD}, \mathrm{DO}, \mathrm{PO}_{4}, \mathrm{NO}_{3}-\mathrm{N}$, $\mathrm{NH}_{3}-\mathrm{N}$, TDS, turbidity and TSS along the selected stretch of the river. The $\mathrm{pH}$ of the river water varied from 6.92 to 7.73 during wet season and ranged from 7.02 to 7.71 during dry season at surface water sampling stations (Figure 3).

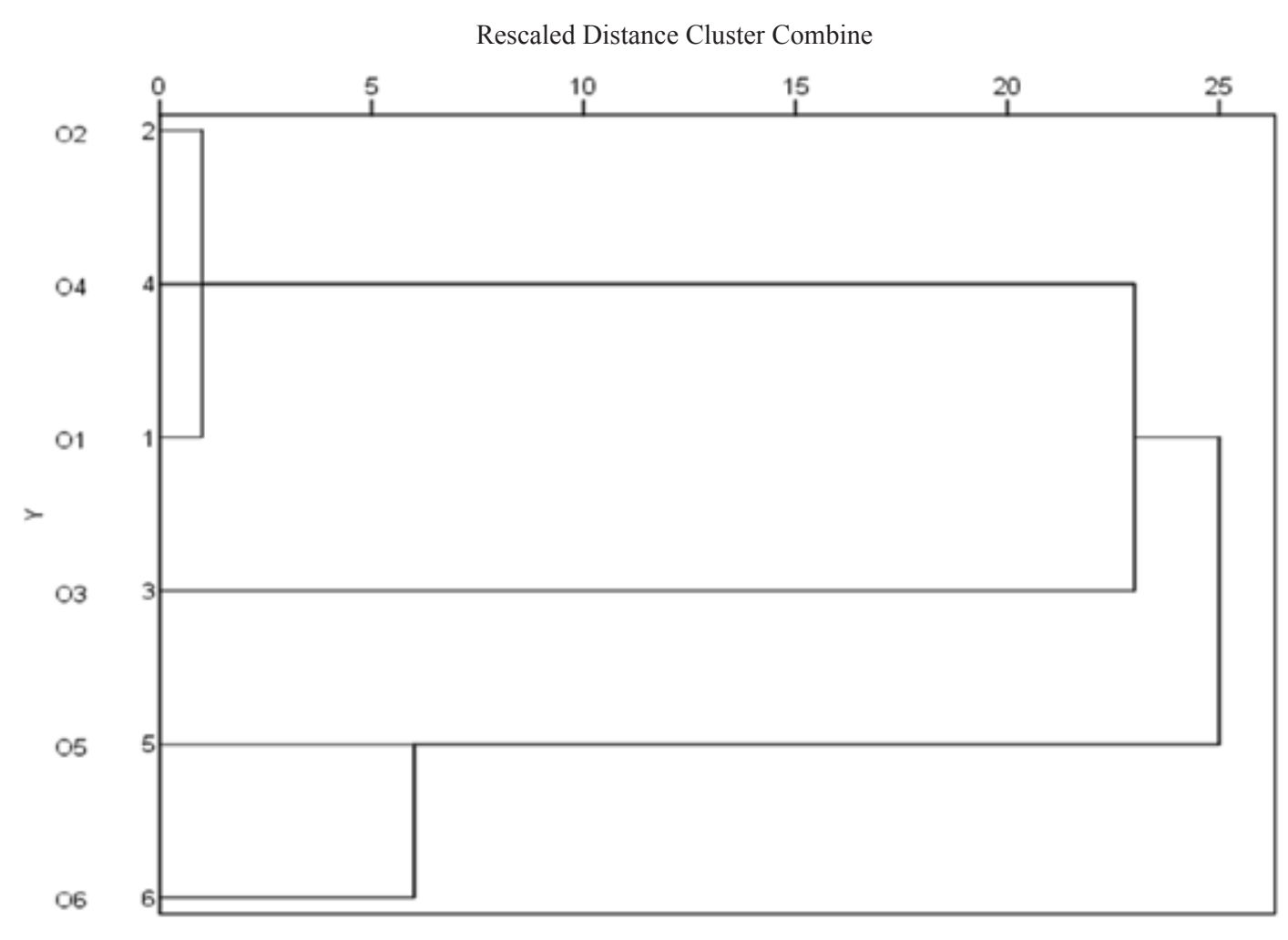

Fig. 2. Dendogram showing the clusters of outfalls based on discharge quality 


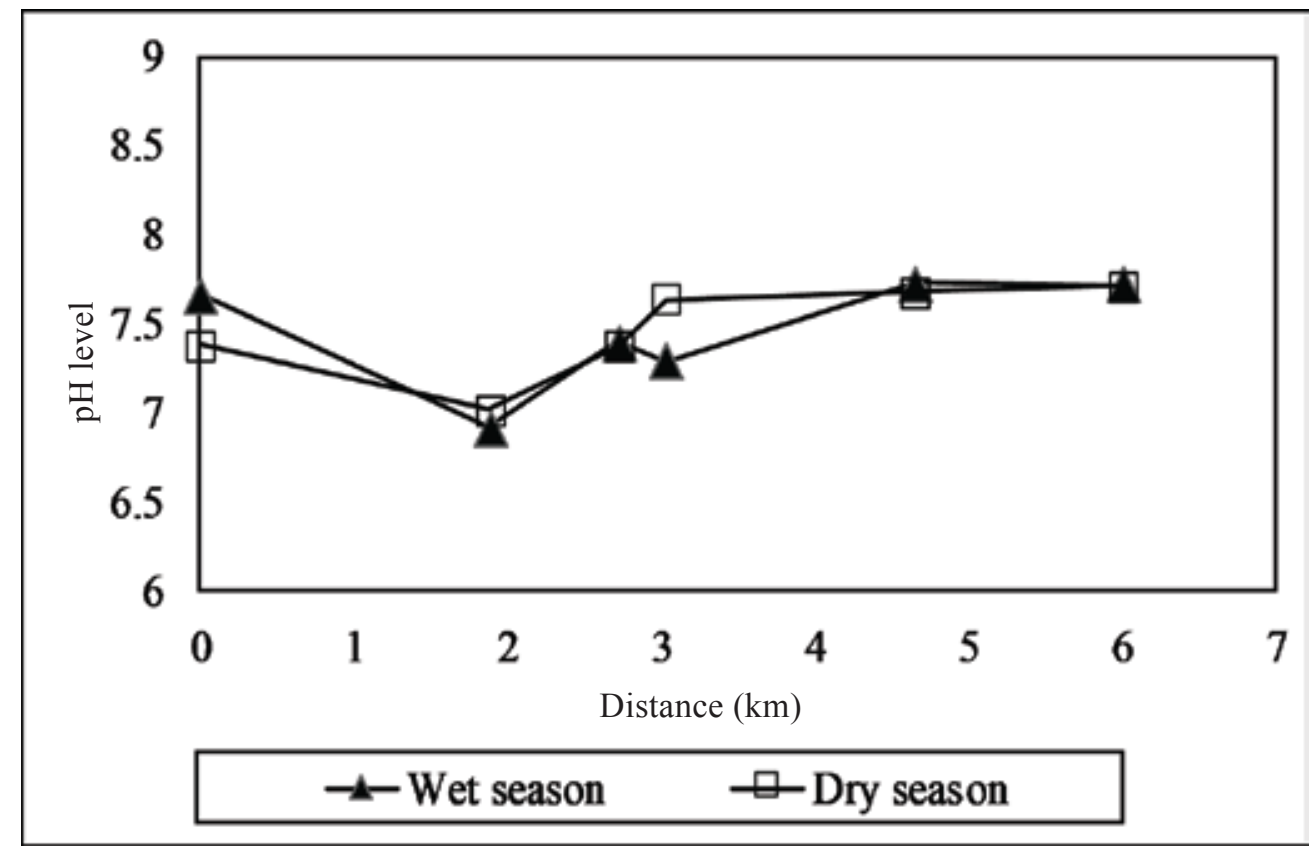

Fig. 3. Seasonal variation of $\mathrm{pH}$ at surface water sampling stations

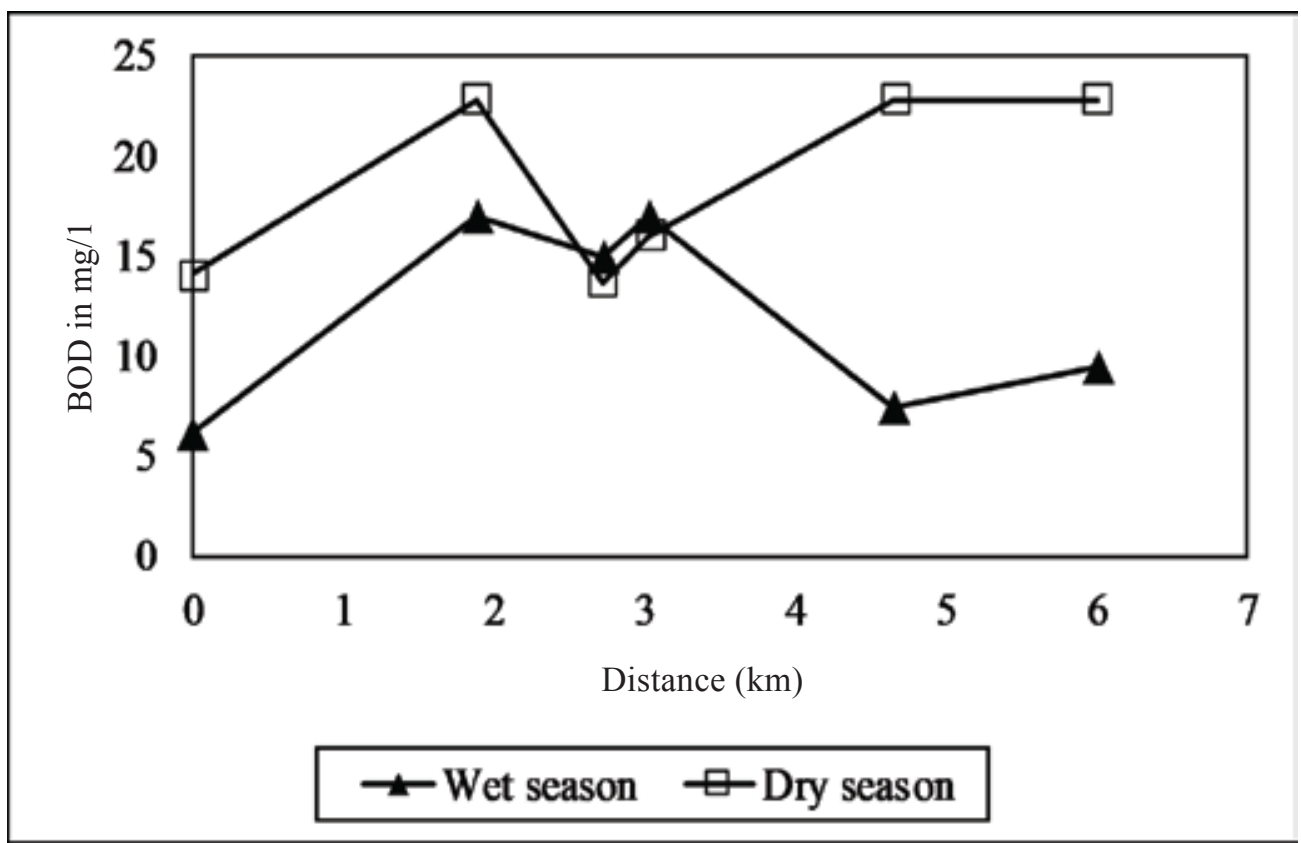

Fig. 4. Seasonal variation of $\mathrm{BOD}_{5}$ at surface water sampling stations 
Observed results of water quality parameters in two different seasons suggested no seasonal variation of $\mathrm{pH}$ level in river water. However, during both the seasons, the highest $\mathrm{pH}$ level was recorded at downstream of the river near industrial zones likely due to the high chemical content discharge from local industrial sources. The $\mathrm{pH}$ level in two different seasons were within the permissible standard for aquatic living standard (ECR, 1997).

Compared to wet season data, the observed level of $\mathrm{BOD}_{5}$ was considerably higher during dry season at most of the sampling stations (Figure 4). The highest $\mathrm{BOD}_{5}(22.8$ $\mathrm{mg} / \mathrm{l})$ between two different seasons was recorded during dry season at three different sampling stations S2, S5 and S6 respectively whereas during wet season, high concentration was obtained at the midstream of the river near the sampling stations S2 and S4. The highest concentration along the downstream occurred allegedly due to the number of industries along this area. Whereas during wet season the high $\mathrm{BOD}_{5}$ level at midstream was observed possibly due to the high municipal waste discharge from Dholaikhal (O2) point. However, the BOD5 value was above the permissible range for aquatic life standard for both the seasons (ECR, 1997).

The COD level varied from 8 to $24 \mathrm{mg} / \mathrm{l}$ during wet season and from 22 to $30 \mathrm{mg} / \mathrm{l}$ during dry season at the selected sampling stations (Figure 5). The highest COD (30 mg/l) was recorded along the midstream of the river at sampling station S3 during dry season and the lowest $(22 \mathrm{mg} / \mathrm{l})$ was obtained at sampling station S4 during dry season. These levels of COD could have occurred possibly due to high amount of textile dye and chemical effluents that are regularly discharged from nearby wastewater sources. However, among the sampling stations, the highest seasonal variation was observed atstationsS5 and S6 (more than 200\%) and minimum level was obtained (below 15\%) at S4.

The DO concentration varied from 3.27 to $4.68 \mathrm{mg} / \mathrm{l}$ during wet season, whereas during dry season, the concentration varied from 1.73 to $2.36 \mathrm{mg} / \mathrm{l}$ (Figure 6). Due to the high precipitation and tidal effects during the wet season in the river, DO level remained higher. However, with the progression of dry season, the water level goes lower and increasing level of pollution causes depletion of DO in river water due to insufficient natural purification. During the wet season, the DO concentration was higher at upstream of the river and lower at downstream of the river. In contrast, the DO level was found higher at downstream of the river and lower at upstream of the river during dry season. Lesser amount of organic wastes from the industrial sources compared to municipal sources are likely to increase DO level at downstream during dry season. According to the standard for aquatic living, during both the seasons, the DO levels were mostly lower than the required specified level (ECR, 1997).

The observed levels of phosphate $\left(\mathrm{PO}_{4}\right)$ were comparatively higher during dry season than those in wet season (Figure 7). During the wet season, the highest value (4.9 $\mathrm{mg} / \mathrm{l})$ was observed at S2 sampling station towards upstream of the river. In contrast, the highest concentration of phosphate was observed at the downstream of the river near industrial zones during dry season. Most of the industries in these areas

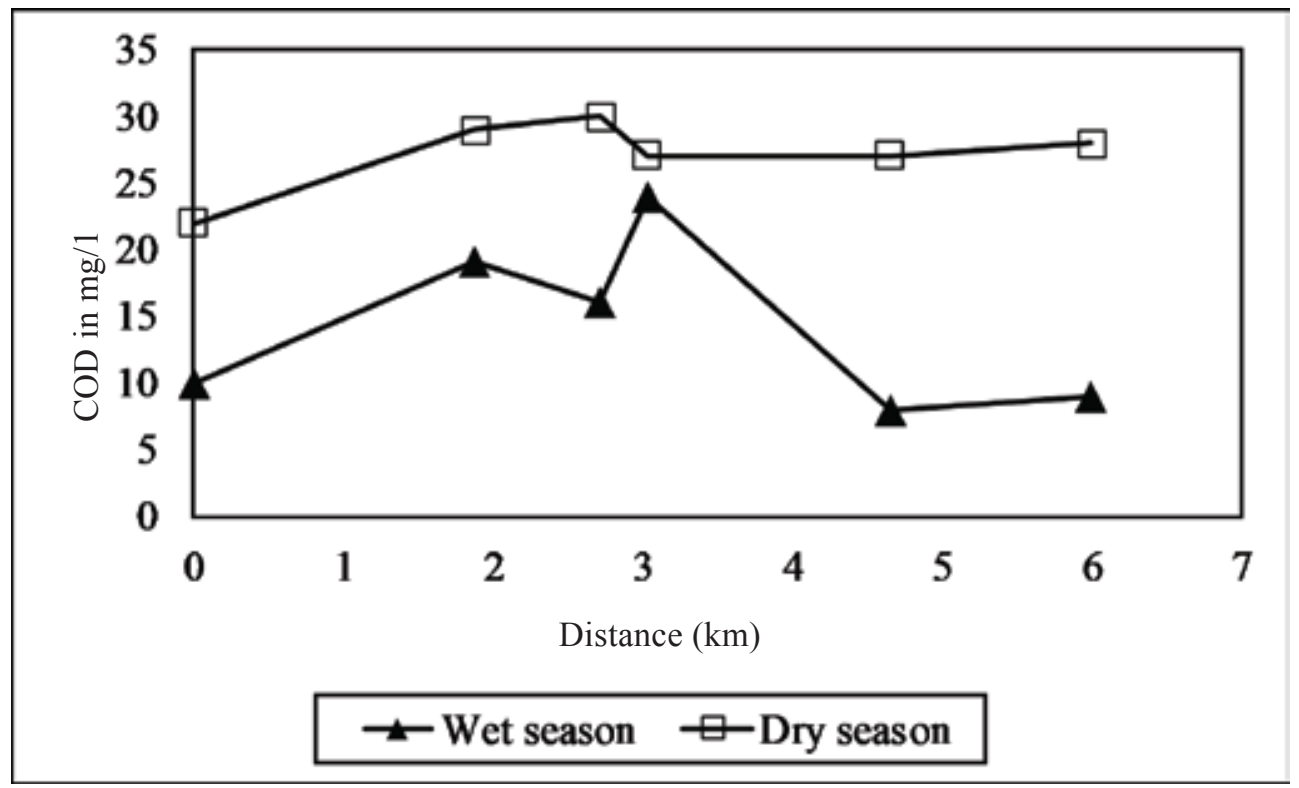

Fig. 5. Seasonal variation of COD at surface water sampling stations 


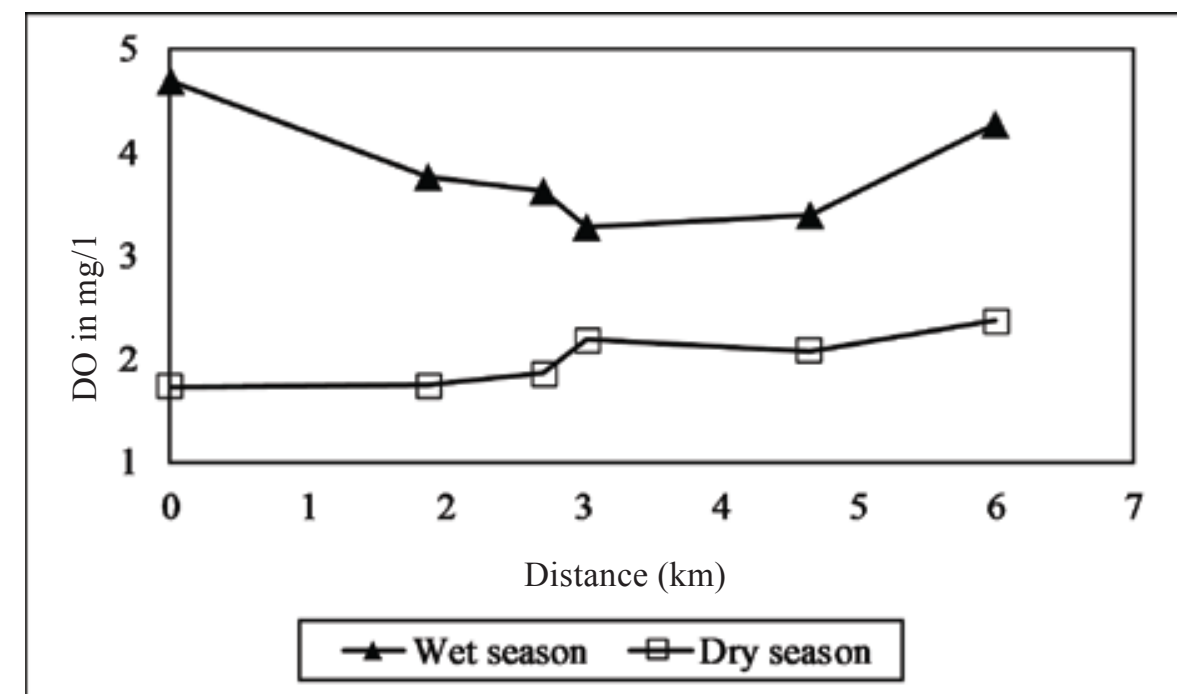

Fig. 6. Seasonal variation of DO at surface water sampling stations

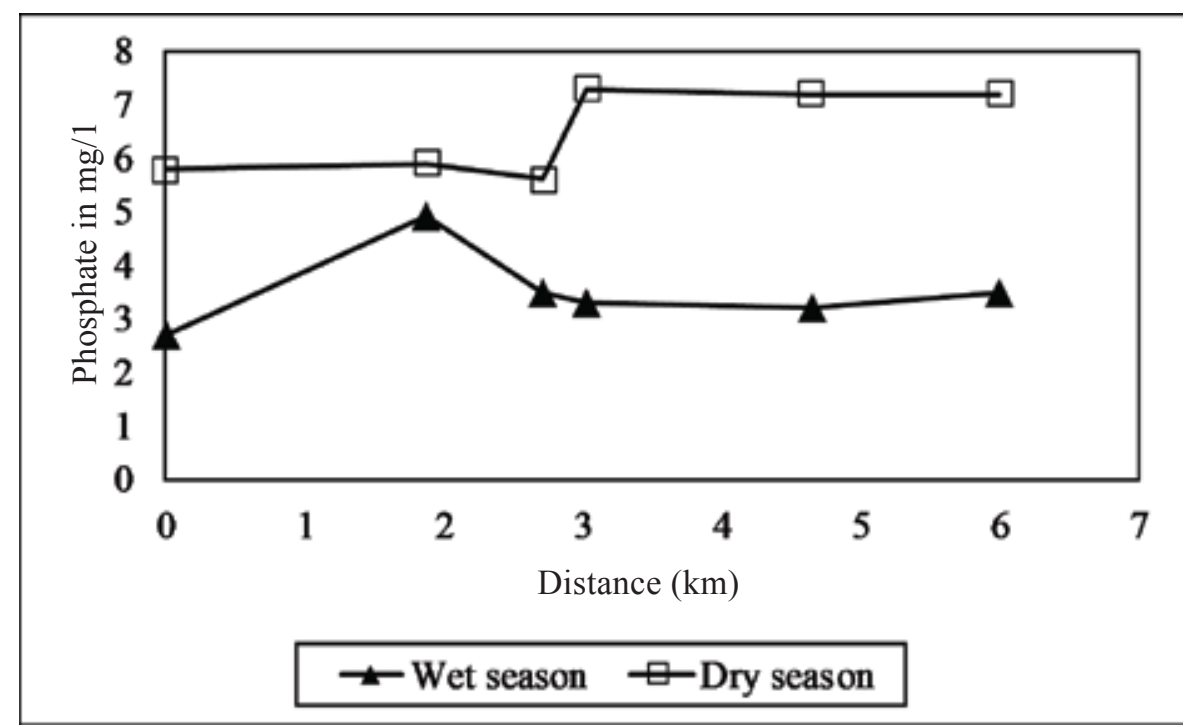

Fig. 7. Seasonal variation of phosphate $\left(\mathrm{PO}_{4}\right)$ at surface water sampling stations

discharge their effluents without treatment in the river, which is the reason of high amount of phosphate in this stretch of the river. However, due to the high precipitation in wet season, the concentration of phosphate was not obtained as high as in dry season along the downstream of the river.

The nitrate-nitrogen $\left(\mathrm{NO}_{3}-\mathrm{N}\right)$ concentration ranged from 0 to $0.6 \mathrm{mg} / 1$ at surface water sampling stations during both the seasons (Figure 8). During wet season, no nitrate concentration was found at the upstream of the river, changing to increased concentration in midstream which gradually decreased towards the downstream of the river. Meanwhile, during dry season, higher concentration was observed at the upstream of the river $(0.5$ to $0.6 \mathrm{mg} / \mathrm{l})$, where municipal wastewater sources are dominating. During both the seasons, the nitrate-nitrogen concentration was lower at downstream of the river near industrial zones, while the highest concentration was obtained at sampling station S3. 


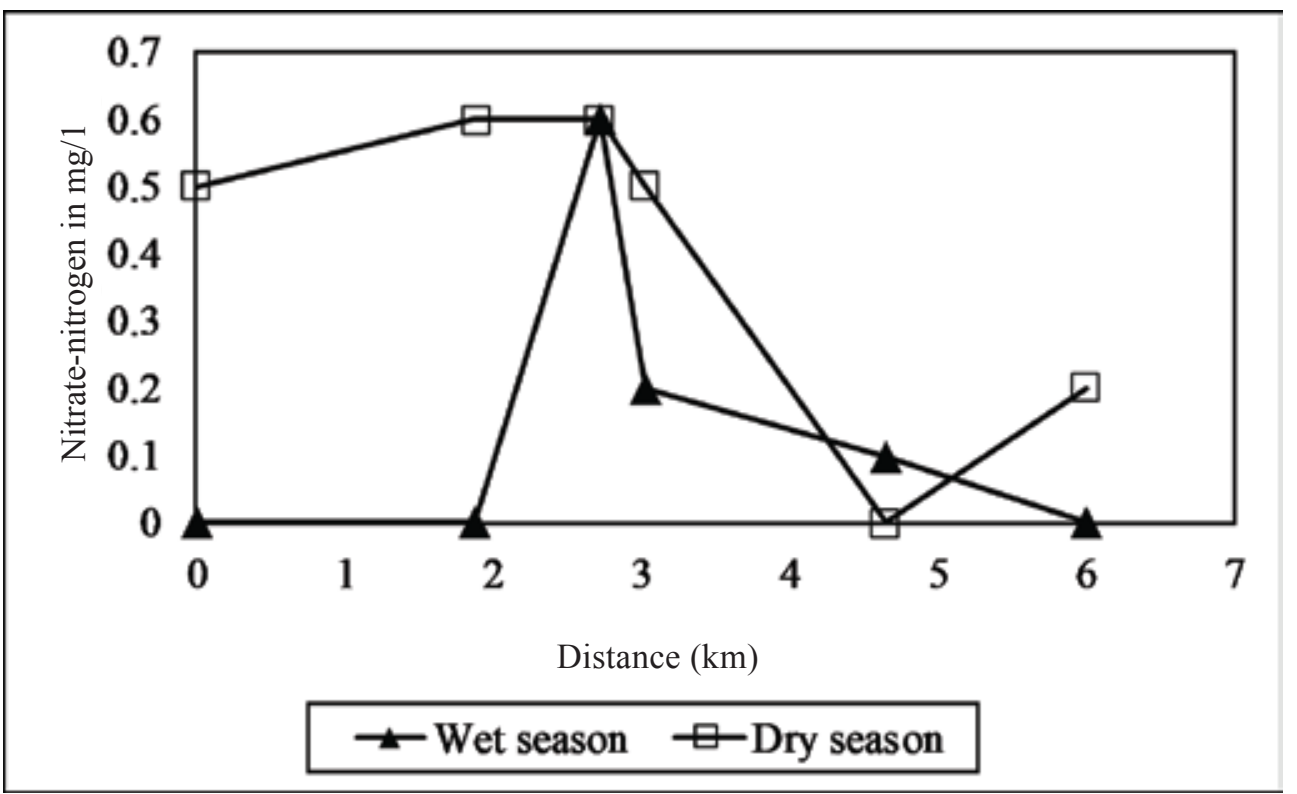

Fig. 8. Seasonal variation of nitrate-nitrogen $\left(\mathrm{NO}_{3}-\mathrm{N}\right)$ at surface water sampling stations

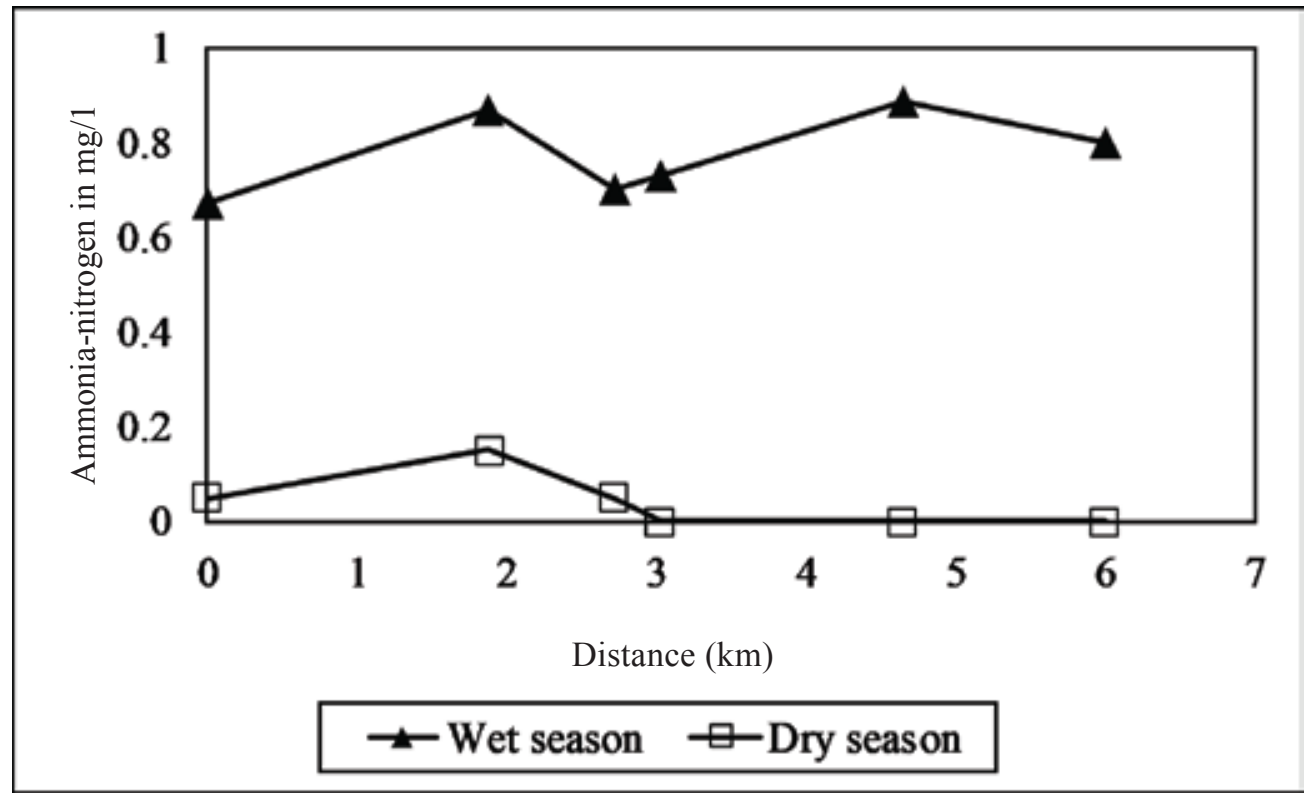

Fig. 9. Seasonal variation of ammonia-nitrogen $\left(\mathrm{NH}_{3}-\mathrm{N}\right)$ at surface water sampling stations

Unlike the other water quality parameters, ammonia-nitrogen $\left(\mathrm{NH}_{3}-\mathrm{N}\right)$ concentration was observed to be high during the wet season than that in the dry season (Figure 9). The ammonia-nitrogen concentration varied from 0.67 to 0.89 $\mathrm{mg} / \mathrm{l}$ during wet season and from 0 to $0.15 \mathrm{mg} / \mathrm{l}$ during dry season. During the wet season, highest ammonia concentration was obtained at the downstream of the river probably due to the highest precipitation and augmented surface water runoff that brings more ammonia compounds in river water. However, during dry season insignificant concentration was observed at downstream of the river.

Total dissolved solids were observed at 63.8 to $86.8 \mathrm{mg} / 1$ during wet season and at 280 to $303 \mathrm{mg} / \mathrm{l}$ during dry season (Figure 10). Meanwhile, total suspended solidwas measured at 16 to $23 \mathrm{mg} / \mathrm{l}$ during wet season and 16 to $37 \mathrm{mg} / \mathrm{l}$ during 


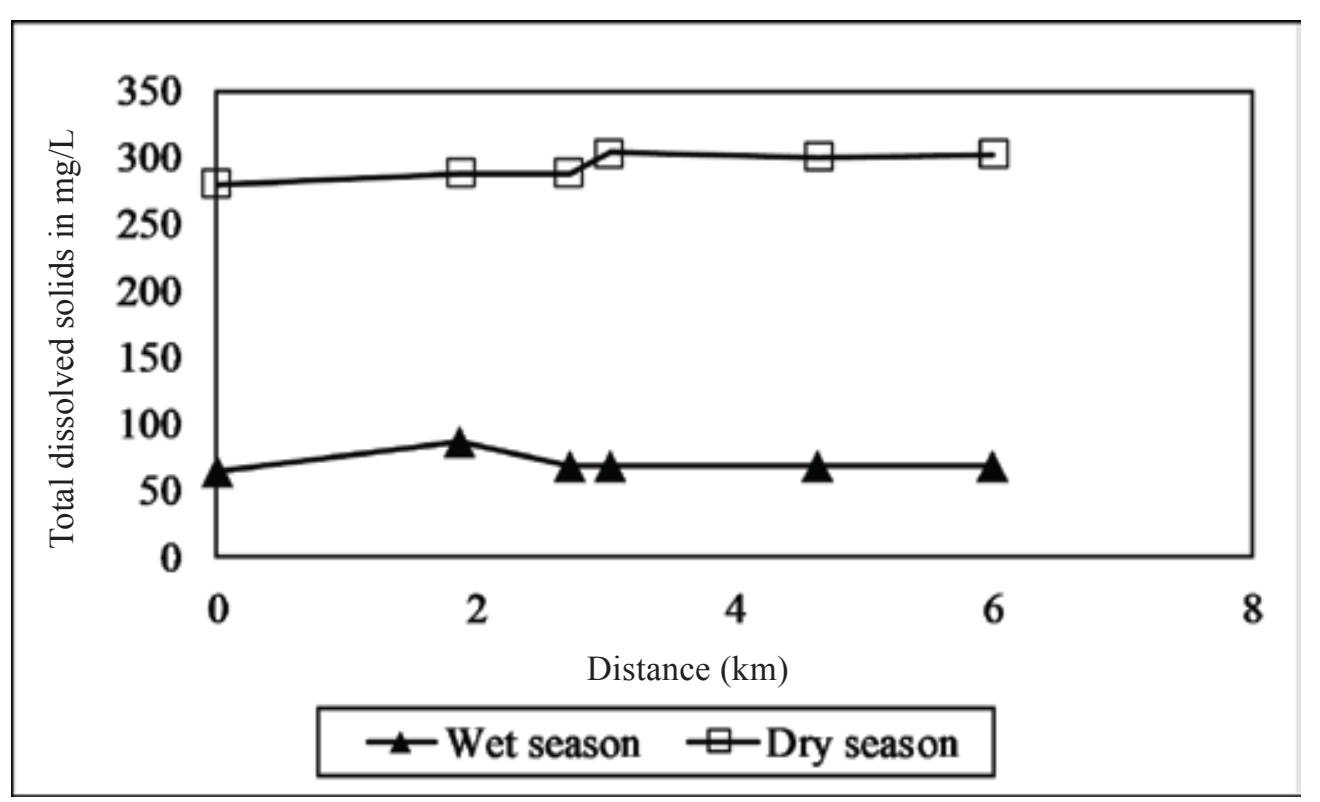

Fig. 10. Seasonal variation of total dissolved solids (TDS) at surface water sampling stations

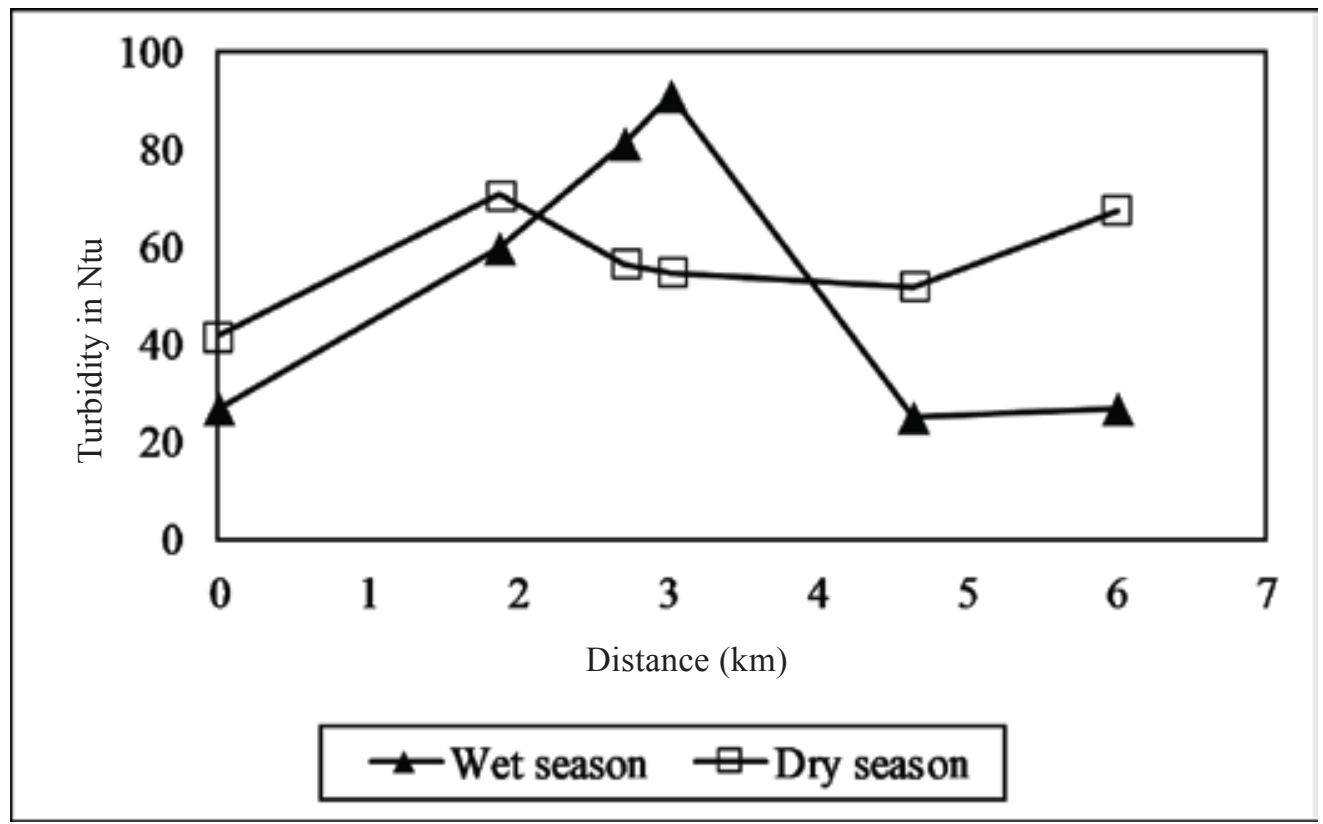

Fig. 11. Seasonal variation of turbidity at surface water sampling stations

dry season (Figure 11). TDS concentrations increased almost 4 times in all the sampling stations during dry season than the wet season data. The highest TDS were observed $86.8 \mathrm{mg} / \mathrm{l}$ during wet season near S2 $(86.8 \mathrm{mg} / \mathrm{l})$ while the highest was at S4 (303) during dry season. Industrial activities at downstream of the river might have caused this high concentration near S4. On the other hand, highest value of TSS was observed at S3 (23 mg/l) during wet season and S6
(37 mg/l) during dry season. Notably, the TSS values were obtained at larger levels at downstream of the river during dry season similar to TDS values.

Turbidity was observed at 25.19 to $91.18 \mathrm{mg} / \mathrm{l}$ during wet season and 41.9 to $70.79 \mathrm{mg} / \mathrm{l}$ during dry season in Buriganga River (Figure 12). Comparing both the seasons, high concentration was observed near the midstream around S3 


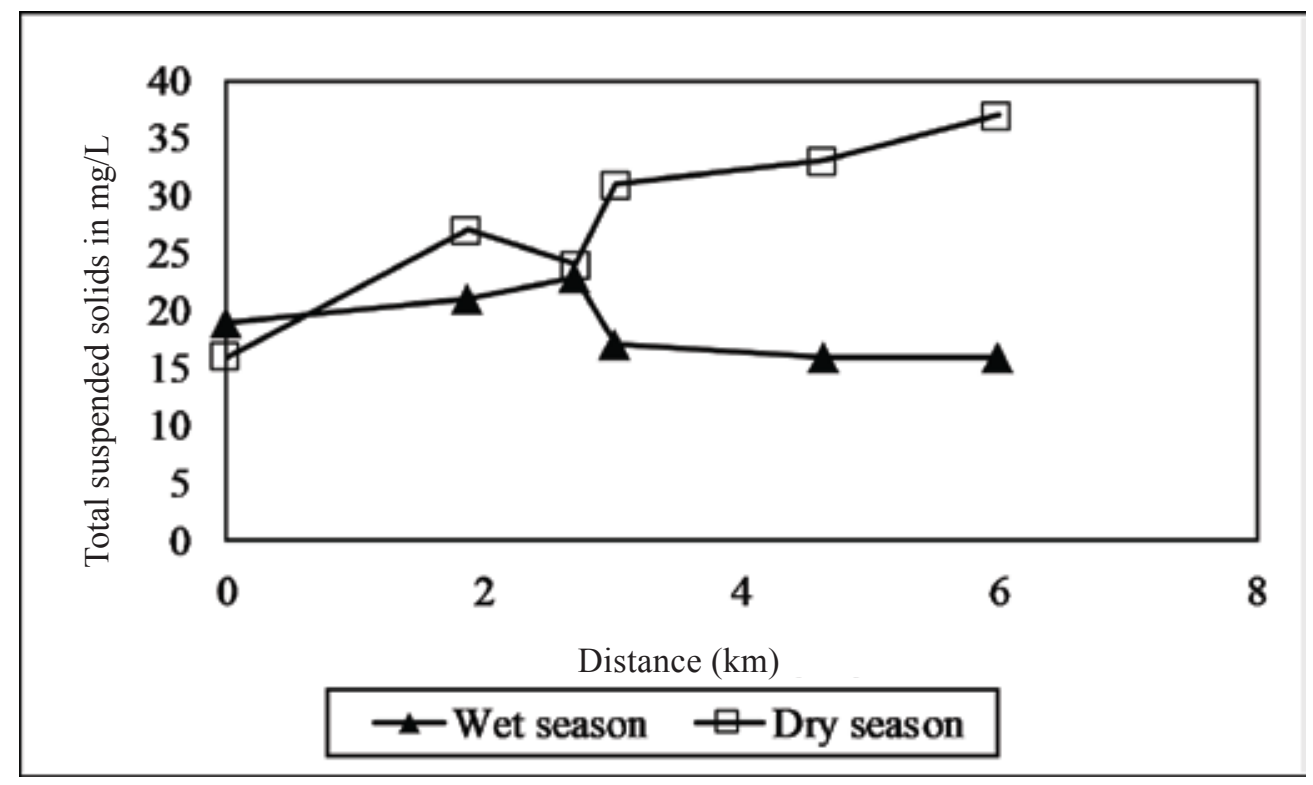

Fig. 12. Seasonal variation of total suspended solids at surface water sampling stations

$(81.05 \mathrm{mg} / \mathrm{l})$ and $\mathrm{S} 4(91.18 \mathrm{mg} / \mathrm{l})$ during the wet season. Apart from this midstream, dry season data was higher than the wet season data at all other sampling stations. Municipal sewage discharges coming from Dholaikhal which is located at downstream near the sampling station S3, S4 in addition to extra rainfall carrying huge amount wastes from local livelihoods might be the reasons behind increased turbidity during wet season.

\section{Principal component analysis of surface water quality}

PCA is a multivariate statistical analysis method which reduces the dimensionality of a data set with large number of inter related variables, it also allows to assess the participation of individual chemicals by several influence factors (Kebede and Kebedee 2012). In this research, PCA were applied for 12 water quality parameters for six different locations of the Buriganga river in two different seasons, the results of which are shown in Tables III and IV. The PC's with eigenvalues over 1 were considered as essential to complete the analysis. The wet seasonal datasets were yielded by 4 PCs, while the dry seasonal dataset had 3 PCs and respectively had a total variance $95.09 \%$ and $95.357 \%$ respectively.

During the wet season, total variance of component 1 had $36.60 \%$ variance which had strong positive loadings on TDS, $\mathrm{PO}_{4}, \mathrm{EC}(>0.95)$ and negative loading on $\mathrm{pH}$ (Table III). Thus, component 1 represented the ionic distribution in the river water and influenced the $\mathrm{pH}$ level. Component 2 is explained by $21.63 \%$ of the total variance and had strong positive loadings on COD (0.787) and strong negative loading on color (0.882). This is due to the organic pollution of the water which affected color of the water quality. On the other hand, component 3 had a positive loading on $\mathrm{NO}_{3}-\mathrm{N}$ and TSS and explained by $21.16 \%$ which suggests the influence of inorganic constituents. These inorganic constituents might have occurred due to the anthropogenic inputs in the river (Ouyang et al., 2006). Whereas, the component 4 having negative loading on DO also suggests organic pollution in the river that caused depletion of DO level.

During the dry season, total variance of component 1 had found $47.51 \%$ variance and had positive loadings on $\mathrm{pH}, \mathrm{DO}$, TDS, EC, $\mathrm{PO}_{4}(>0.80)$ and strong negative correlation $\mathrm{NH}_{3}-\mathrm{N}$ (Table IV). Thus, component 1 is reflecting the mineral and inorganic nutrients $\left(\mathrm{PO}_{4}, \mathrm{NH}_{3}-\mathrm{N}\right)$ (Kebede and Kebedee 2012). These constituents were mostly influenced by the DO level in the river during dry season. Component 2 was found to have strong positive loading on COD, Turbidity and strong negative loading on color and explained by $30.32 \%$. This explains the degradation of the river water quality in terms of color and turbidity due to the organic pollution. While the component 3 had a strong negative loading on $\mathrm{BOD}_{5}$ and $\mathrm{NO}_{3}-\mathrm{N}$ and explained by $17.54 \%$. The component 2 and 3 again displaying sign of high organic pollution sign and influence of domestic pollution sources.

To summarize, results indicated that during the wet season, the parameters TDS, $\mathrm{PO}_{4}$, DO and EC had a high loading 
Table II. PCA analysis of surface water quality parameters for wet season

\begin{tabular}{lllll}
\hline Indicator & \multicolumn{4}{c}{ Component } \\
\cline { 2 - 5 } & \multicolumn{1}{c}{1} & \multicolumn{1}{c}{3} & 4 \\
\hline $\mathrm{pH}$ & -0.742 & -0.590 & -0.298 & -0.105 \\
$\mathrm{BOD}_{5}$ & 0.511 & 0.509 & 0.456 & 0.455 \\
$\mathrm{COD}$ & 0.263 & 0.787 & 0.341 & 0.360 \\
$\mathrm{DO}$ & -0.151 & -0.271 & 0.007 & -0.934 \\
$\mathrm{NO}_{3}-\mathrm{N}$ & -0.215 & -0.048 & 0.816 & 0.491 \\
$\mathrm{NH}_{3}-\mathrm{N}$ & 0.637 & -0.284 & -0.604 & 0.347 \\
$\mathrm{TDS}$ & 0.983 & 0.172 & 0.007 & 0.043 \\
$\mathrm{TSS}$ & 0.353 & 0.137 & 0.849 & -0.175 \\
Turbidity & 0.108 & 0.591 & 0.601 & 0.502 \\
$\mathrm{PO}$ & 0.981 & 0.082 & 0.097 & 0.116 \\
$\mathrm{Color}$ & -0.079 & -0.882 & 0.060 & -0.061 \\
EC & 0.983 & 0.172 & 0.006 & 0.043 \\
Eigenvalue & 4.393 & 2.595 & 2.539 & 1.884 \\
Total variance \% & 36.609 & 21.626 & 21.155 & 15.70 \\
Cumulative variance \% & 36.609 & 58.235 & 79.390 & 95.090 \\
\hline
\end{tabular}

Table III. PCA analysis of surface water quality parameters for dry season

\begin{tabular}{llcl}
\hline Indicator & \multicolumn{3}{c}{ Component } \\
\cline { 2 - 4 } $\mathrm{pH}$ & 0.968 & -0.185 & 0.098 \\
$\mathrm{BOD}_{5}$ & 0.077 & 0.149 & -0.718 \\
$\mathrm{COD}$ & 0.015 & 0.931 & -0.084 \\
$\mathrm{DO}$ & 0.905 & 0.292 & 0.187 \\
$\mathrm{NO}_{3}-\mathrm{N}$ & -0.612 & 0.149 & -0.718 \\
$\mathrm{NH}_{3}-\mathrm{N}$ & -0.945 & 0.278 & 0.049 \\
$\mathrm{TDS}$ & 0.848 & 0.434 & 0.243 \\
$\mathrm{TSS}$ & 0.664 & 0.606 & 0.438 \\
Turbidity & -0.132 & 0.916 & 0.261 \\
$\mathrm{PO}_{4}$ & 0.868 & 0.131 & 0.386 \\
Color & -0.335 & -0.793 & -0.485 \\
EC & 0.792 & 0.556 & 0.206 \\
Eigenvalue & 5.701 & 3.638 & 2.104 \\
Total variance \% & 47.508 & 30.316 & 17.534 \\
Cumulative variance \% & 47.508 & 77.824 & 95.357 \\
\hline
\end{tabular}


$(>0.9)$ and constituted the main pollution factors in the river. Meanwhile, during dry season, the parameters $\mathrm{pH}$, DO, $\mathrm{NH}_{3}-\mathrm{N}$, Turbidity, $\mathrm{COD}(>0.9)$ could be identified as the main pollution factors in the river. Though during wet season, ionic parameters (EC, TDS) and $\mathrm{PO}_{4}$ were explained by as high as $36.6 \%$ variance but during dry season $\mathrm{DO}, \mathrm{pH}$, $\mathrm{NH}_{3}-\mathrm{N}$ were explained by $47.50 \%$ variance. It eventually appeared from the PCA analysis that during the dry season organic pollution was the main pollution factor in the river than wet season as $\mathrm{DO}$ and $\mathrm{NH}_{3}-\mathrm{Nwere}$ explained by high variance.

\section{Spatial distribution of water quality parameters}

The spatial distributions of water quality parameters within the study area were obtained through processing of surface water quality data obtained during two different seasons in a GIS based krigging method. The GIS outputs are shown in Figure 13. The GIS representation enabled a comparative assessment of the distribution of the water quality parameters through the entire reach of the river and graphical categorization was possible from severely polluted zone to comparatively less polluted zone. Most of the water quality parameters were found in lowest concentrations at the upstream of the river during wet season. The high level of DO (4.40-4.68 mg/l), low $\mathrm{BOD}_{5}$ and Turbidity during wet season indicated that this portion of the river was comparatively pollution free and that wastewater sources were less polluted. In contrast, during dry season, high concentration of $\mathrm{NO}_{3}-\mathrm{N}$ and lowest DO level $(1.72-1.85 \mathrm{mg} / \mathrm{l})$ indicated pollution from organic matter from the nearest wastewater sources, most likely due to increased number of municipal wastewater sources in this area. GIS distribution revealed high concentrations ofBOD $, \mathrm{NO}_{3}-\mathrm{N}, \mathrm{COD}$ and lower $\mathrm{DO}$ in both the seasons between the stations S2 and S4, signifying the mid portion of the river to be the severely polluted zone within the study area. During the wet season, $\mathrm{BOD}_{5}, \mathrm{NO}_{3}-\mathrm{N}$, Turbidity, $\mathrm{COD}$ and $\mathrm{PO}_{4}$ were highest in this region and showed reduction in DO level from the upper reaches of the river. While, during the dry season $\mathrm{BOD}_{5}, \mathrm{COD}, \mathrm{NO}_{3}-\mathrm{N}$, $\mathrm{NH}_{3}-\mathrm{N}$ found highest for this region. Moreover, considering seasonal variation, notable reduction was observed during dry season in $\mathrm{BOD}_{5}$ and $\mathrm{DO}$ level than the wet season. The water quality parameters $\mathrm{NH}_{3}-\mathrm{N}, \mathrm{BOD}_{5}$ and lower $\mathrm{DO}$ of this region is affected by the huge amount of municipal waste discharge from the Dholaikhal $(\mathrm{O} 2)$ and $\mathrm{NO}_{3}-\mathrm{N}, \mathrm{COD}$ was affected by the textile industry effluents from the source $\mathrm{O} 3$ and $\mathrm{O} 4$. The distribution of DO levels at downstream of the river between $\mathrm{S} 4$ to $\mathrm{S} 6$ were acceptable than the upper reaches during both of the seasons. Meanwhile, during the dry season, $\mathrm{BOD}_{5}, \mathrm{COD}$, Turbidity, TDS and $\mathrm{PO}_{4}$ were found to be higher at downstream and unlike wet season, low
$\mathrm{NH}_{3}-\mathrm{N}$ and high $\mathrm{PO}_{4}$ levels were observed. In the downstream zone, high $\mathrm{COD}, \mathrm{PO}_{4}$, TDS level is due to the increasing number of industries and high DO level is the result of less organic pollutant from these industrial sources. However, after the water quality distribution map it can be concluded that water quality in river water was highly influenced by the discharging wastewater sources along the river bank.

\section{Waste loading characteristics of outfalls}

The estimated waste loading data for two different seasons in a map of study area along with the outfalls locations are shown in Figure 14. With a $\mathrm{BOD}_{5}$ loading rate of 11,681 $\mathrm{kg}$ /day during wet season and $12,243 \mathrm{~kg}$ /day during dry season, outfall $\mathrm{O} 2$ discharges more than 500 times of $\mathrm{BOD}_{5}$ during wet season and more than 35 times during dry season compared to the other municipal outfall $\mathrm{O} 1$ considered in this study. Though the previous loading rate of $\mathrm{BOD}_{5}$ reported for O2 in the study (Kamal, 1999) was much higher $(29,980$ $\mathrm{kg} /$ day) than the present study. Concentration of $\mathrm{BOD}_{5}$ was also at $220 \mathrm{mg} / \mathrm{l}$ in the previous study which is much higher than the present data. Thus, the pollution scenario changes substantially with the sources of wastewater discharge into the river especially alongside the relocation of industries. Apart from $\mathrm{BOD}_{5}$, the outfall $\mathrm{O} 2$ is also the highest waste contributor for TDS (32348 kg/day), TSS (13703 kg/day), COD $(19544 \mathrm{~kg} /$ day $)$ and $\mathrm{PO}_{4}(5616 \mathrm{~kg} /$ day $)$ during dry season. However, observed results for $\mathrm{PO}_{4}$ loading in present study are observed to be higher than the mentioned loading for O2 in previous study (Kamal, 1999). The observation made among the municipal outfalls led to the result that the major municipal pollution source in the study area was outfall O2. Meanwhile, outfall O6 was the highest waste load contributor at the river among all the industrial sources in this study. Among the industrial sources, highest $\mathrm{BOD}_{5}(1700$ $\mathrm{kg} /$ day), COD (3886 kg/day), TSS (3754 kg/day)was obtained at $\mathrm{O} 6$ during the wet season, whereas highest levels of TDS (3978 kg/day) and $\mathrm{PO}_{4}(570 \mathrm{~kg} /$ day $)$ were obtained during dry season. Similar to outfall O6, O5 was found to contribute high amount of waste loading in the Buriganga river. High waste loading rate from the outfall $\mathrm{O} 6$ and $\mathrm{O} 5$ is due to the large flow rate and size of the out falls than the other industrial wastewater source O3. High COD and TDS at the outfalls is likely due to the chemical wastes and dye injected from the local textile industries. Most of the outfalls were found to discharge high concentration of wastewater during dry season than the wet season, with the exception at O6. The reduced waste loading rate during dry season is probably due to the large fluctuation in flow from wet to dry season. Overall, the waste loading data suggested outfall $\mathrm{O} 2$ (Dholai khal) to be the major pollution route in the Buriganga river than the other selected outfalls in the study area. 
(a)

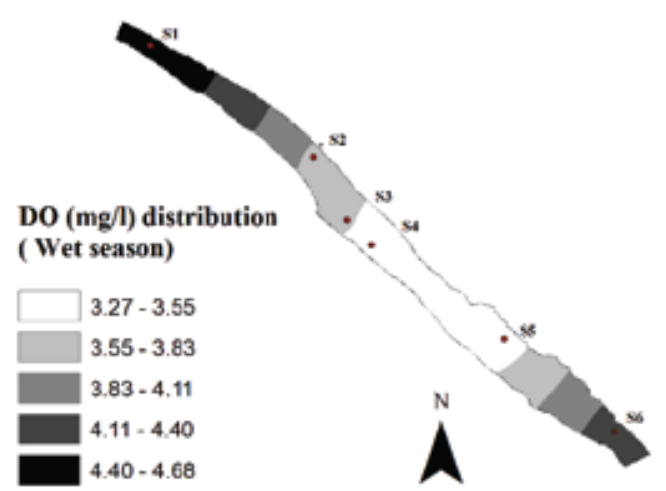

(b)

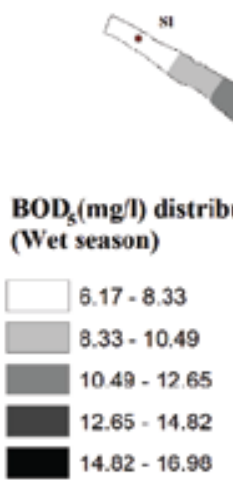

(c)

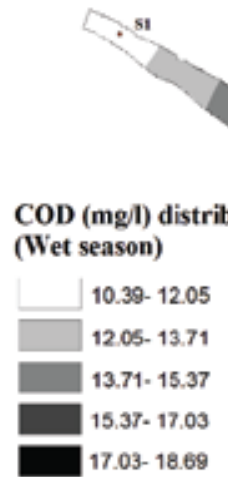

(d)

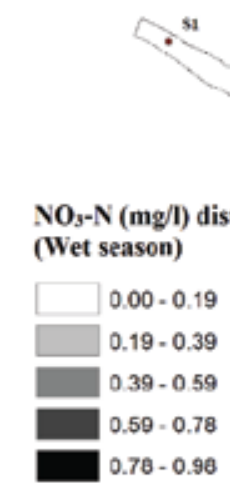

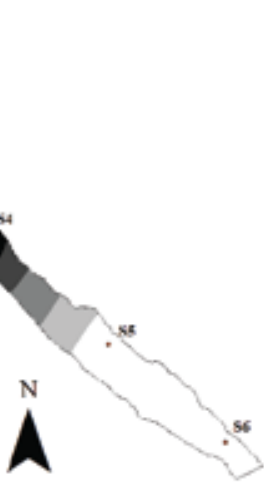

N
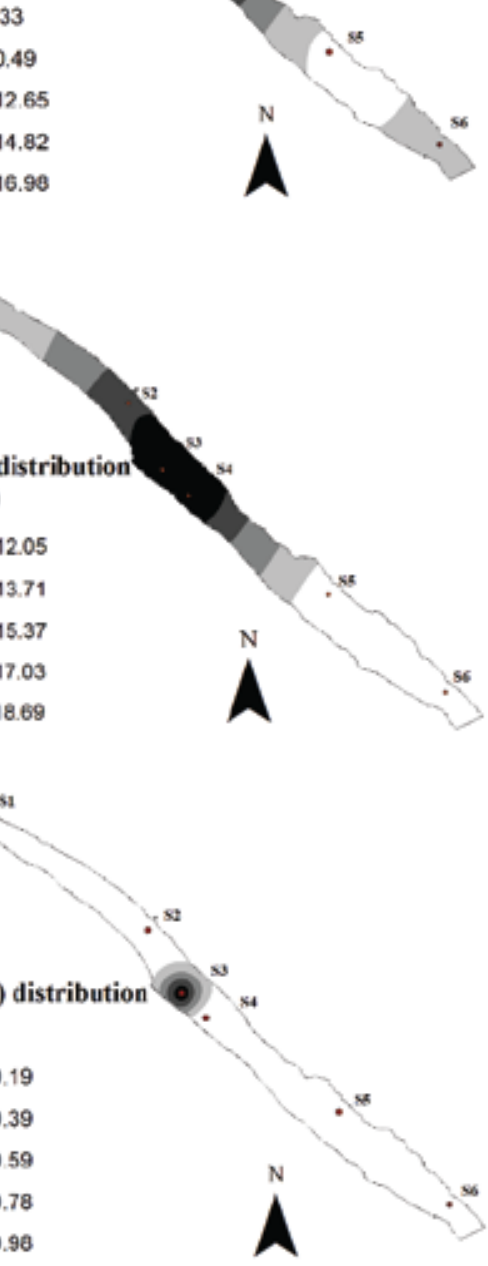
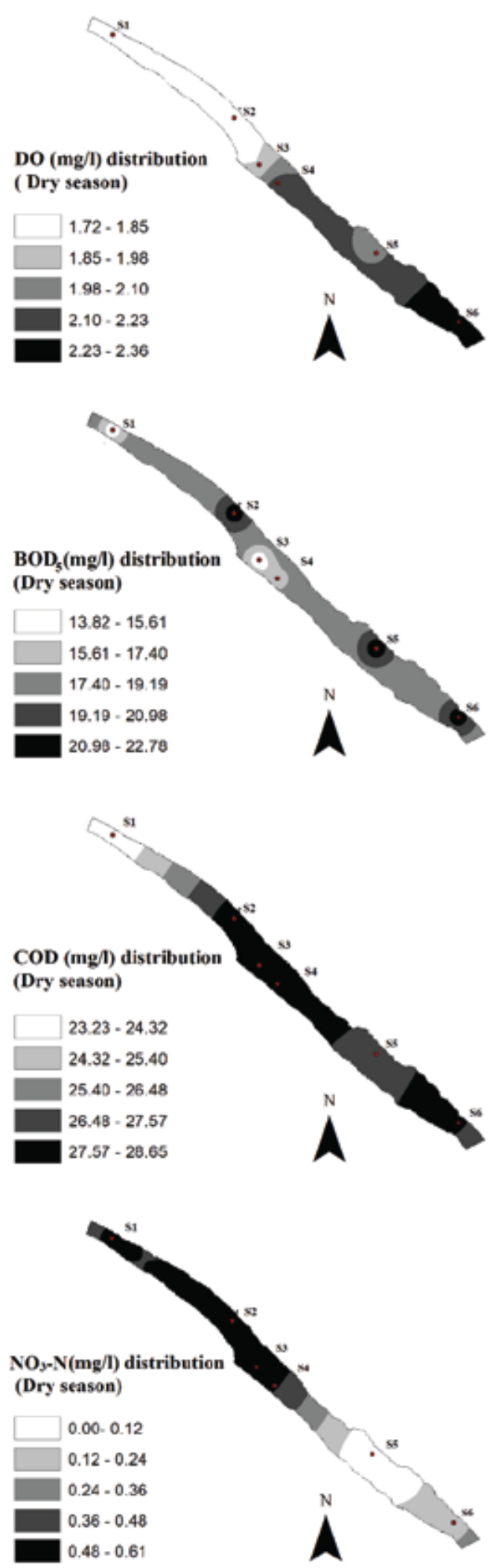
(e)

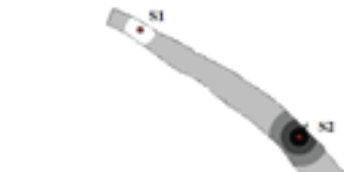

$\mathrm{PO}_{4}$ (ma/l) distribution (Wet season)
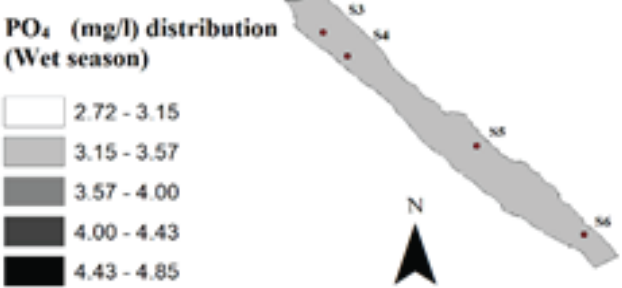

$\mathrm{PO}_{4}(\mathrm{mg} / \mathrm{l})$ distribution (Dry season)

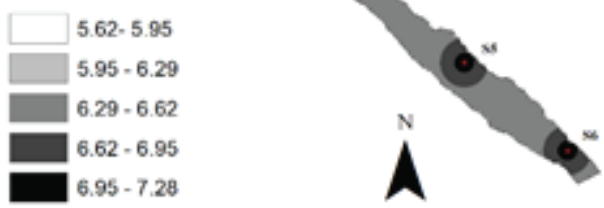

(f)
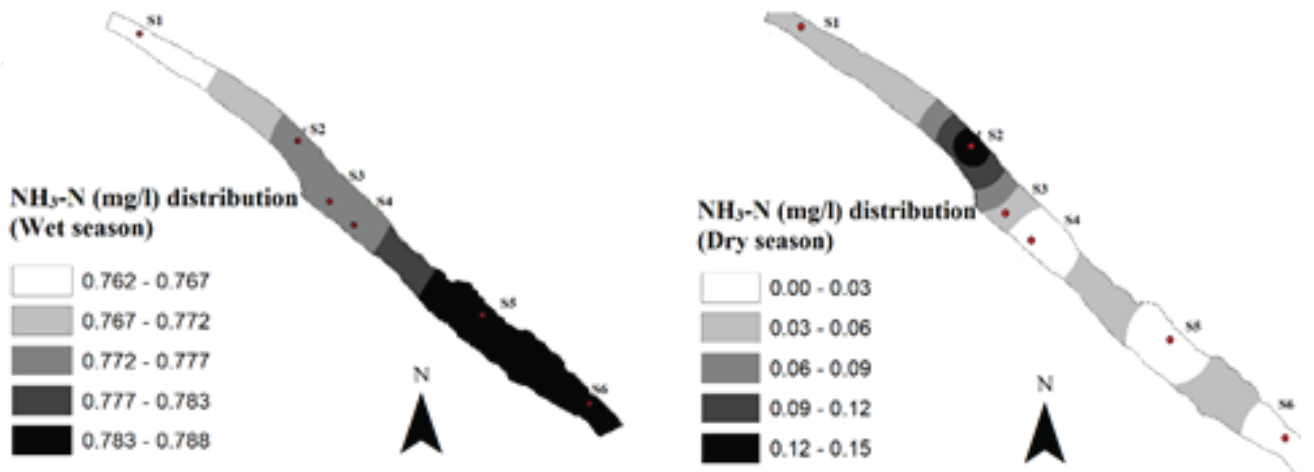

$(\mathrm{g})$
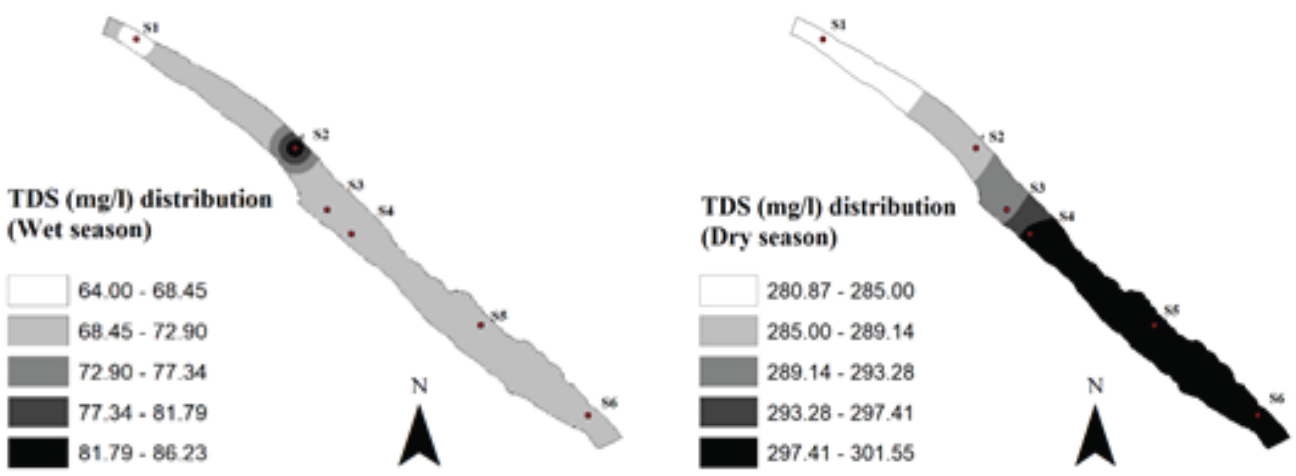

(h)
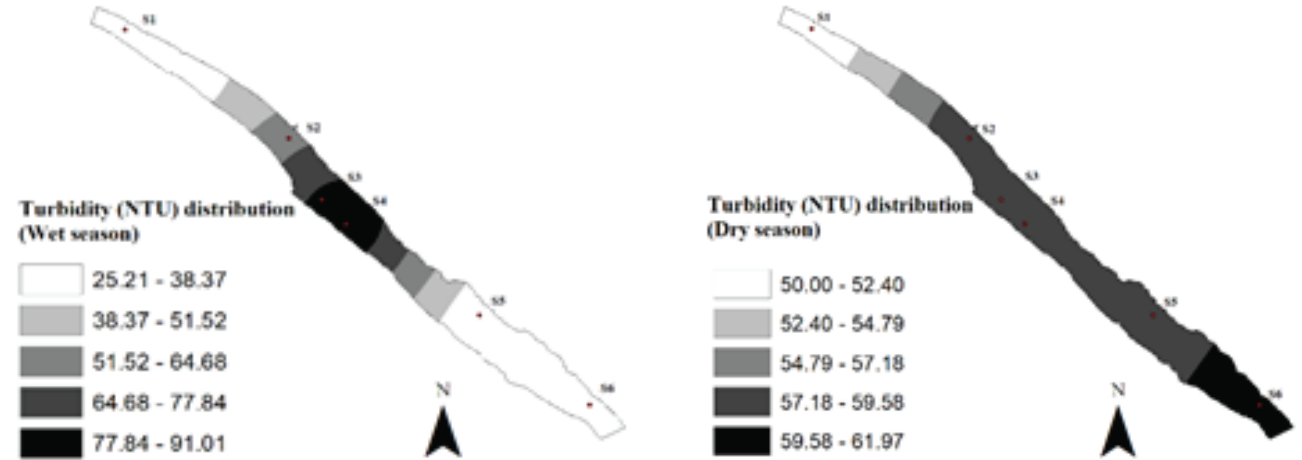

Fig. 13. Spatial distribution of water quality parameters during dry and wet season through GIS mapping: (a) $\mathrm{BOD}_{5}$; (b) COD; (c) DO; (d) $\mathrm{PO}_{4}$; (e) $\mathrm{NO}_{3}-\mathrm{N}$; (f) $\mathrm{NH}_{3}-\mathrm{N}$; (g) TDS; (h) Turbidity 


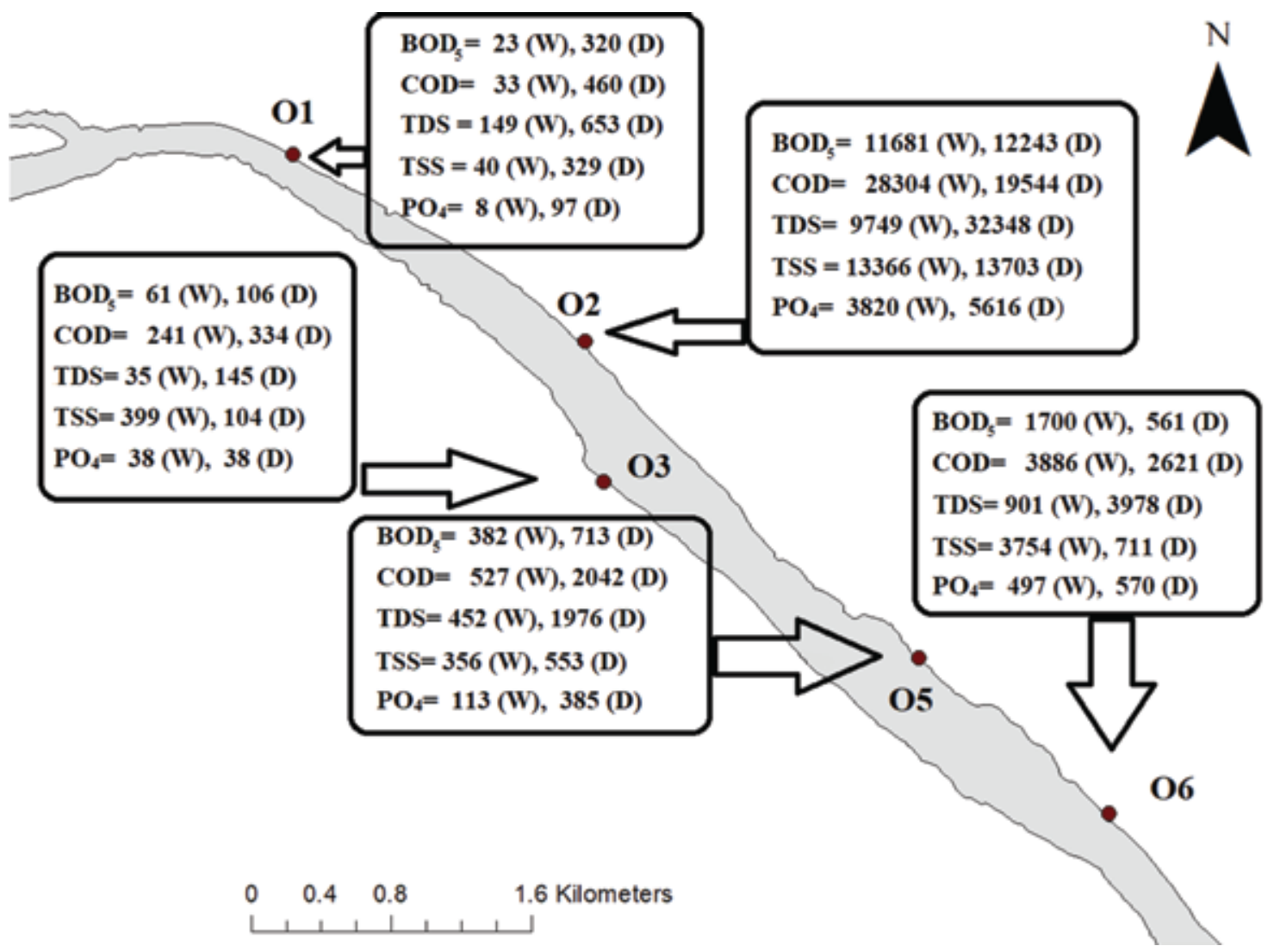

Fig. 14. Waste loading rates in $\mathrm{kg} / \mathrm{day}$ for $\mathrm{BOD}_{5}, \mathrm{COD}, \mathrm{TDS}, \mathrm{TSS}$ and $\mathrm{PO}_{4}$ of selected outfalls during wet (W) and dry season (D) [outfall $\mathrm{O} 4$ was omitted during load calculation]

However, dry season flow rate was utilized for waste load calculation for both the seasons which might have caused an underestimation in the waste loading estimation for wet season.

\section{Conclusion}

This study combines the statistical technique and GIS analysis work to identify current pollution status of Buriganga River in the selected study area. The research work also identified major wastewater outfalls and characterized outfalls discharge in the selected study area. The characterization included the chemical analysis of water quality parameters and waste loading measurement of the outfalls. Water quality parameters TDS, TSS, EC and COD were obtained in high concentration from industrial outfalls at downstream of the river and $\mathrm{BOD}_{5}, \mathrm{PO}_{4}, \mathrm{NH}_{3}-\mathrm{N}$ were higher mainly from municipal wastewater outfalls at upstream of the river. In addition, lack of treatment of industrial effluents before discharging into the river was observed as most of the discharge quality of the outfalls exceeded the discharge standard. Assessment of seasonal variation of surface water quality concluded that during dry season the pollution status of the river becomes severe. According to the guidelines of water quality established in Environment Conservation Rules, the river water is in vulnerable situation for existence of aquatic living. The PCA analysis identified high ionic distribution (TDS, EC)during wet season while organic pollutants were the main pollution factors ( $\left.\mathrm{DO}, \mathrm{NH}_{3}-\mathrm{N}, \mathrm{COD}\right)$ during dry season. Moreover, the GIS spatial distribution data and waste loading data revealed that major pollution source in the study area is Dholaikhal discharging point $(\mathrm{O} 2)$ and the major outfall discharging industrial effluent is $\mathrm{O} 6$ at downstream of the river near Pagla. The surface water quality and the outfall discharge observation concluded that the surface water quality parameters are highly influenced by nearest wastewater sources. Thus, proper treatment of wastewater before discharging into the river water is strongly recommended. However, as pollution status shows significant improvement during wet season, the study of hydrological parameters during the wet season may be sought to learn about the 
impact of river hydrological characteristics on pollution status of the river. Finally, adequate coverage of sewerage system all around the city is the ultimate solution to prevent the current pollution level along the river.

\section{References}

Ahammed SS, Tasfina S, Rabbani KA and Khaleque MA (2016), An Investigation into The Water Quality of Buriganga River Running Through Dhaka. International Journal of Scientific \& Technology Research 5(3): 36-41.

APHA (1992), Standard Methods for the Examination of Water and Wastewater, eighteenth ed. American Public Health Association, Washington, DC.

DWASA (2014), Annual Report 2013-14, Dhaka Water and Sewage Supply Authority, p 48.

ECR (1997), Environment Conservation Rules, Department of Environment. Ministry of Environment and Forest, People's Republic of Bangladesh.

Gao H, Lv C, Song Y, Zhang Y, Zheng L, Wen Y and Yu H (2015), Chemometrics data of water quality and environmental heterogeneity analysis in $\mathrm{Pu}$ River, China. Environmental Earth Sciences 73(9): 5119-5129.

Hach CC, Klein JR, RL and Gibbs CR (1997), Introduction to Biochemical Oxygen Demand. Technical information series, Booklet no. 07

Haque MI (2008), Water Resource Management in Bangladesh. $1^{\text {st }}$ Ed. (Anushilanprakashani, Dhaka), p 80 .

Ian H, Sarah C and Steve C (2001), An Introduction to Geographical Information Systems. $2^{\text {nd }}$ Ed. (Pearson Education, India), p 117.

Jirka AM and Carter MJ (1975), Micro semiautomated analysis of surface and waste waters for chemical oxygen demand. Analytical chemistry, 47(8): 1397-1402.

Kamal MM (1996), Assessment of Impact of Pollutants in the River Buriganga Using a Water Quality Model. M. Sc. Engineering Thesis, Bangladesh University of Engineering and Technology, Dhaka.

Kamal MM, Malmgren-Hansen A and Badruzzaman ABM (1999), Assessment of pollution of the River Buriganga, Bangladesh, using a water quality model.
Water science and technology 40(2): 129-136.

Kebede YK and Kebedee T (2012), Application of principal component analysis in surface water quality monitoring. In Principal Component Analysis-Engineering Applications. In Tech Open.

Moniruzzaman M, Elahi SF and Jahangir MAA (2009), Study on temporal variation of physico-chemical parameters of Buriganga river water through GIS (Geographical Information System) Technology. Bangladesh Journal of Scientific and Industrial Research 44(3): 327-334.

Ouyang Y, Nkedi-Kizza P, Wu QT, Shinde D and Huang CH (2006), Assessment of seasonal variations in surface water quality. Water research 40(20): 3800-3810.

Rahman MA and Bakri DA (2010), A Study on Selected Water Quality Parameters along the river Buriganga, Bangladesh. Iranica Journal of Energy \& Environment 1(2): 81-92.

Rahman MR and Rana MY (1996), Pollution Assimilation Capacity of Buriganga River. J Civil Eng (Bangladesh) CE24, pp 85-95.

Rahman S and Hossain F (2008), Spatial Assessment of Water Quality in Peripheral Rivers of Dhaka City for Optimal Relocation of Water Intake Point. Water Resources Management 22(3): 377-391.

Sabit MI (2011), Evaluation of water quality and pollution sources of Gulshan Lake. M. Sc. Engineering Thesis, Bangladesh University of Engineering and Technology, Dhaka.

Saifullah AS M, Kabir MH, Khatun A, Roy S and Sheikh MS (2013), Investigation of Some Water Quality Parameters of the Buriganga River. Journal of Environmental Science and Natural Resources 5(2): 47-52.

Sarkar M, Rahman AL, Islam JB, Ahmed KS, Uddin MN and Bhoumik N C (2015), Study of hydrochemistry and pollution status of the Buriganga River, Bangladesh, Bangladesh Journal of Scientific and Industrial Research 50(2): 123-134.

Sarker MAK (2005), Study on the Accumulation and Seasonal Variation of Trace Metals in Water, Sediment and Some Fishes of the Buriganga River. M.Sc thesis (1998-1999), Department of Zoology, Dhaka University, Dhaka, Bangladesh, pp 1-4. 
SWMC (Surface Water Modelling Centre) (1996), Water Quality Modelling of the Buriganga-Lakhya River System, Calibration Report. River Research Institute, Government of Bangladesh.

Vega M, Pardo R, Barrado E and Deban L (1998), Assessment of seasonal and polluting effects on the quality of river water by exploratory data analysis. Water Research, Vol. 32: No. 12, pp 3581-3592.
Zhang Y, Guo F, Meng W and Wang XQ (2009), Water quality assessment and source identification of Daliao river basin using multivariate statistical methods. Environmental Monitoring and Assessment 152(1-4): 105. 